\title{
Inequality in Desegregation: Black School Closings
}

Where racially segregated residential patterns exist, the constitutional duty to desegregate a formerly dual school system can be accomplished by two alternate methods. The first and most obvious method involves busing black and white students among previously segregated schools. The second method entails busing black students, but eliminates reciprocal busing of white students by closing formerly black schools. ${ }^{1}$ From the perspective of many white parents, the second alternative has several advantages. First, the white student is relieved of the inconveniences inevitable in any busing plan. Second, the white student avoids confrontation with what is considered an inferior environment. In some instances, the facilities of the black school will not be comparable to its white counterpart. More often, anxiety will be focused on general conditions in the black neighborhood-crime, drugs, gangs, and general urban blight. ${ }^{2}$ Third, the white student escapes association with a school disdained by some whites as a "Negro institution."3

The interests opposing the closing of the black schools are also signifi-

1 School boards achieve the same result by conversion rather than closing. The Department of Health, Education and Welfare has "noted a practice of converting a formerly black school to a special school or a vocational school or of converting a formerly black high school to a desegregated junior high school while having the white high school continue to serve as a high school. . . Proving racial motivation in such instances is less likely, in general." Letter from Robert E. Smith, Assistant Director for Public Affairs, Office for Givil Rights, Department of Health, Education and Welfare, to The University of Chicago Law Review, Apr. 11, 1972 [hereinafter cited as Smith Letter]. Hart v. County School Bd., No. 71-1791 (4th Cir., May 1, 1972), approved the conversion of two black elementary schools into special-purpose institutions. Wright v. Board of Pub. Instruction, 431 F.2d 1200 (5th Cir. 1970), approved the conversion of a formerly black high school into a compensatory education center. Trahan v. Lafayette. Parish School Bd., 330 F. Supp. 450 (W.D. La. 1971), sustained conversion into a vocational center. Such schemes enable the vast majority of whites to escape the possibility of intercommunity busing.

2 Minority schools have generally not been provided with the proper teachers, facilities, or funds. See generally U.S. Advisory CoMm's on CIVIL DIsORDERs, REPORT 424-36 (1968). "Where pupils are to be bused into schools which are outside their residential neighborhoods, sub rosa fears of culturcide and educational retardation may surface in such passive forms as organizations like National Action Group, or in such active forms as the bombing of the empty school buses in Pontiac, Michigan." Brown, Busing as a Permissible Tool in Desegregation, 1 BLACK L.J. 222, 224 (1971).

3 School names such as "Booker T. Washington," "George Washington Carver," and "Martin Luther King" have symbolic meaning for white as well as black students. Fiss, The Charlotte-Mecklenburg Case-Its Significance for Northern School Desegregation, 38 U. ChI. L. REv. 697, 704 (1971). 
cant. First, there are certain tangible effects on the black community. The burden of busing is placed disproportionately on black students; ironically, those most educationally deprived must also endure the greatest loss of time due to travel. Also, schools provide valuable community facilities for recreation, social, and civic functions; ${ }^{4}$ black students may lose along with their community school an administration sensitive to community needs. ${ }^{5}$ Moreover, elimination of black schools may perpetuate the poverty and inferior municipal services prevalent in many black communities by allowing the white community to remain insulated from those realities. Intercommunity busing, on the other hand, promotes a fundamental mutual interest in an environment in which both black and white students spend a major portion of their school years. ${ }^{6}$ Finally, there is the devastating intangible effect of second-class citizenship. The symbolic impact of school closings has particular significance to blacks; ${ }^{8}$ the unavoidable implication is that black schools are not good enough for white students and that the cost of integration for the black community is the loss of its schools.

4 Note, 83 Harv. L. REv. 1434, 1436 (1970). One court responded with empathy to a black protest meeting following a school closing: "[T] he court takes notice of the understandably strong feeling in the Negro community against the closing of what they describe as "their' fine school." Green v. School Bd., Civil No. 1093, at 2 (W.D. Va., Aug. 11, 1970). The existence of these school closing challenges represents a remarkable evolution of black identity within a relatively short time. As late as 1960 , blacks were voluntarily effecting the closing of black schools by mass transfers to newly opened opportunities in previously white institutions. See Fiss, Racial Imbalance in the Public Schools: The Constitutional Concepts, 78 HARv. L. REv. 564, 615 n.109 (1965). Indeed, parents who failed to transfer their children were sometimes vilified as "Uncle Toms," and the black leadership demanded abandonment of schools that in their view were symbols of segregation. U.S. Conni'N on Crvil Rights, Civil Rights U.S.A.-Public Schools, Cities iN the North AND WEST 93 (1962). The desire to escape the black environment has thus been transformed into a determination to create quality educational opportunities within the black community itself.

5 In a case challenging a "tracking" system in a newly integrated school, the court noted that when black schools were closed, "not only did the blacks lose their school, they also lost their principal and the educational policy of using a graded structure." Moses v. Washington Parish School Bd., 330 F. Supp. 1340, 1342 (E.D. La. 1971).

(6) Intercommunity busing may be one of the effective responses to the Walker Commission's warning that "our nation is moving toward two societies, one black, one whiteseparate and unequal." U.S. ADVISORY CONm'N ON CIVIL Disorders, supra note 2, at 1 .

7 "Given demographic trends and housing patterns, one-way busing would mean busing only inner city blacks and other minorities out to the predominantly white suburbs. This would unfairly place all the burdens of busing on one racial group, easily produce dichotomous attitudes of 'bused kids' and 'natives,' and be culturally chauvinistic. An equitable busing plan must serve as a means of equalizing the opportunity of students to take the fullest advantage of educational opportunities, not exacerbate existing inequities between races." Brown, supra note 2, at 224.

8 Note, supra note 4, at 1436. See also Note, 5 Harv. Crv. Rights-Crv. LiB. L. Rev. 488 (1970). 
Since school boards are susceptible to the pressures of majority opinion, the inclusion of black school closings as part of school system integration plans is easily explained. More surprising, however, is the reluctance of federal courts to consider constitutional challenges to black school closings. This comment will analyze (1) the efficacy of the intent standard for reviewing administrative decisions to close black schools, (2) the educational reason defense, (3) the problem of white flight, and (4) the practical and legal considerations relevant to defining a proper standard for review.

\section{Present Elements of Review}

\section{A. The Intent Standard}

Traditional deference to administrative discretion has thwarted effective challenge to black school closings. Although expressing sympathy for the problems confronting blacks, courts often hold that the school closing issue relates solely to the administrative judgment of the school board and thus fails to present a constitutional question. ${ }^{9}$ Other courts have stated that if the school closing decision is based on neutral rather than explicitly racial categories, no equal protection problem arises.

In Norwalk CORE v. Norwalk, ${ }^{10}$ for example, the Second Circuit confronted the problem in the context of a voluntary desegregation plan undertaken by the Gity of Norwalk in order "to give every child in Norwalk the best possible education."11 Three schools in predominantly black and Puerto Rican areas were closed, at least one of which was completely modern and fully adequate. ${ }^{12}$ The school board had carefully considered the social and economic characteristics of the neighborhoods involved, as well as the existence of racial hostilities and fears, and had selected for integration schools in those neighborhoods where it concluded that a more effective educational environment could be maintained.13 Although the busing burden clearly fell most heavily on blacks, the court found that the closing of the nonwhite schools did not

9 "[T] he court understands and sympathizes with [the school board's] failure to keep Mann open as a high school. .. The Court ... thinks now that the question of whether to keep Mann open as a high school or whether to make other use of it was one that addressed itself to the administrative judgment of the Board and that it was not of constitutional magnitude." Clark v. Board of Directors, 328 F. Supp. 1205, 1218 (E.D. Ark. 1971). See also United States v. Midland Independent School Dist., 334 F. Supp. 147, 151 (W.D. Tex. 1971), in which the court believed that "their neighborhood schools should be left intact, but the failure of the school board to do this does not present a constitutional question."

10423 F.2d 121 (2d Cir. 1970).

11 Id. at 122.

12 See id. at 125 (Kaufman, J., dissenting).

13 Norwalk CORE v. Norwalk Bd. of Educ., 298 F. Supp. 213, 218 (D. Conn. 1969). 
violate the fourteenth amendment, noting that "[a]lthough people are equal and governmental classification by race will not be tolerated, neighborhoods are not. Reasonable administrative discrimination between neighborhoods in determining the location of public facilities such as schools is not subject to judicial intervention where those facilities remain available for use by all ...."14

Even those courts willing to intervene in school closing decisions apply very narrow standards of review. The Fifth Circuit, where the majority of cases arise, has held that only a showing of a racially discriminatory motive will prevent the closing of formerly black schools. ${ }^{15}$ Thus, courts have found denials of equal protection where black school closings are based solely on the reluctance of the school board to require white students to attend schools in black areas. ${ }^{10}$ This intent standard also voids closings based on fears that whites will flee the public school system. As one court held, "an otherwise useful building may not be closed merely because the school board speculates that whites will refuse to attend the location."17

Use of the intent standard to protect against discriminatory administrative decision making is, however, subject to severe infirmities. Motive is a very elusive factor, ${ }^{18}$ and unless courts are willing to infer discriminatory intent from the fact that black schools alone are closed, the doctrine merely provides protection against the unwise and unin-

14 Norwalk CORE v. Norwalk Bd. of Educ., 423 F.2d 121, 124 (2d Cir. 1970).

15 "The rule in this circuit ... is that such closings are prohibited where undertaken for racial reasons of the type that may be equated with invidious discrimination." Mims v. Duval County School Bd., 447 F.2d 1330, 1331 (5th Cir. 1971). See also Lee v. Macon County Bd. of Educ., 448 F.2d 746 (5th Cir. 1971); Bell v. West Point Municipal Separate School Dist., 446 F.2d 1362 (5th Cir. 1971); Brown v. Board of Educ., 446 F.2d 75 (5th Cir. 1971); Allen v. Board of Pub. Instruction, 432 F.2d 362 (5th Cir. 1970); Carr v. Montgomery County Bd. of Educ., 429 F.2d 382 (5th Cir. 1970).

16 Allen v. Board of Instruction, 312 F. Supp. 1127, 1135 (S.D. Fla. 1970). In voiding a school closing decision, one court noted that "white people are willing for the colored children to come to the white sections of town to go to the white schools but the white people are not willing to let their children go to the colored section. I think that is the reason and we might as well tag it for what it is." Quarles v. Oxford Municipal Separate School Dist., Civil No. WC6962-K, at 4 (N.D. Miss., Jan. 8, 1970).

17 Bell v. West Point Municipal Separate School Dist., 446 F.2d 1362, 1363 (5th Cir. 1971). See also Gordon v. Jefferson Davis Parish School Bd., 330 F. Supp. 1119, 1122 (W.D. La.), aff'd, 466 F.2d 266 (5th Cir. 1971).

18 Recently, the Supreme Court focused on the elusive quality of intent in a case in which a local governing body closed a swimming pool for allegedly racial motives: "It is difficult or impossible for any court to determine the 'sole' or 'dominant' motivation behind the choices of a group of legislators." Palmer v. Thompson, 91 S. Ct. 1940, 1945 (1971). Moreover, an intentional-unintentional distinction is merely another version of the de facto-de jure standard that has permitted continued segregation in Northern school systems. The focus should instead be on the effect of the school board's actions rather than the underlying intent. Fiss, supra note 3, at 704-05 (1971). 
formed discriminator who verbalizes his racial motive. Moreover, even if evidence of racial motive can be adduced from the fact that only black schools are closed, the presence of a nonracial rationale supporting the school closing provides a complete defense to claims of discriminatory intent. "The corollary of [the intent] rule," the courts state, "is that schools, black and white, may be closed for non-racial reasons." 19 As a result, the protection offered to blacks is only temporary; a nonracial, educationally valid reason can almost always be found to satisfy such a test. ${ }^{20}$ Even should a school closing be voided initially because of discriminatory intent, a subsequent closing of the same school would pass constitutional muster if done for different reasons. ${ }^{21}$

Finally, by declaring that the intent of individual school board members is irrelevant, some courts have sharply limited the possibilities for proving racial motive. In Allen v. Asheville, ${ }^{22}$ for example, the Fourth Circuit upheld the closing of two black schools because the white schools were "newer and physically better." 23 In the absence of a showing that the decision was "so unfair that it clearly amounts to invidious discrimi-

19 Mims v. Duval County School Bd., 447 F.2d 1330, 1331 (5th Cir. 1971). "It is undisputed that a school may be terminated for sound educational reasons." Bell v. West Point Municipal Separate School Dist., 446 F.2d 1362 (5th Cir. 1971).

20 The suggestion of Judge Clark, concurring in a similar remand decision, makes it apparent that an initial expression of racial motivation will delay but not prevent the closing of black schools. Bell v. West Point Municipal Separate School Dist., 446 F.2d 1362, 1364 (5th Cir. 1971).

21 The Supreme Court recently noted that "there is an element of futility in a judicial attempt to invalidate a law because of the bad motives of its supporters. If the law is struck down for this reason, rather than because of its facial content or effect, it would presumably be valid as soon as the legislature or relevant governing body repassed it for different reasons." Palmer v. Thompson, 9I S. Gt. 1940, 1945 (1971). In dicta, Judge Wisdom has suggested a possible change in the intent standard presently applied by the Fifth Circuit. In Lee v. Macon County Bd, of Educ., 448 F.2d 746 (5th Gir. 1971), prior to the litigation, the school board had abandoned its plan to close a black school. Nevertheless, Judge Wisdom indicated that on the facts presented, the school closings would have been unconstitutional. Although other reasons may have existed for the closings, the court stated that "the primary reason for closing the schools was the county board's conclusion that the use of the black facilities would lead whites to withdraw from the public system." Id. at 754. Such a primary intent standard would allow challenge of school closings even where educational reasons could be shown. Moreover, the recent decision in Bivins v. Bibb County Bd. of Educ., No. 71-2983 (5th Cir., May 3, 1972), also suggests that the Fifth Gircuit may soon become more responsive to black school closing claims. Remanding to the district court for consideration of alternative plans aimed at creating a unitary school system, the court added: "In so doing, the district court should further bear in mind that the burdens of closed schools and being bussed should not fall unequally on the minority race." $I d$. at 6.

22434 F.2d 902 (4th Cir, 1970). See also Hart v. County School Bd., 329 F. Supp. 953 (E.D. Va. 1971).

23 Id . at 906. 
nation," 24 the court refused to consider whether the school board's decision was supported by substantial evidence. Moreover, it effectively vitiated the intent standard ${ }^{25}$ by declaring that administrative intent, and not the intent of school board members, was the determinative factor. Since the school board's overriding intent was to achieve a unitary school system, the black school closings were permissible. ${ }^{26}$

\section{B. The Educational Reasons Defense}

Under all of the standards presently applied by courts, the existence of "valid" educational reasons for closing black schools justifies discrimination among neighborhoods and vitiates any equal protection claims. The educational reasons defense has not, however, provided adequate protection to the black community. Courts have found a broad range of factors relevant to the educational process, including small size of school site, ${ }^{27}$ need for new school to serve expanding suburban population, ${ }^{28}$ proximity of schools to scrap metal yard, ${ }^{29}$ minimal surrounding acreage ${ }^{30}$ poor accessibility to students,, 31 area undesirable for congregating children, ${ }^{32}$ desire for better physical environment, ${ }^{33}$ highly noxious odors, ${ }^{34}$ glass and cans percolating through landfill underlying school grounds, ${ }^{35}$ high crime area, ${ }^{38}$ violence in school, ${ }^{37}$ difficulty in maintain-

24 Id. But cf. Green v. School Bd., Givil No. 1093 (W.D. Va., Aug. 11, 1970), in which the court found that there were no sufficient reasons to justify closing a facility that was less than twenty years old, well-built, and located on a ten-acre lot. Id. at 7 .

25 Previously, the Fourth Circuit had applied an intent standard. See Chambers v. Iredell County Bd. of Educ., 423 F.2d 613 (4th Cir. 1970), in which the court upheld a school closing on the ground that the plaintiffs had not sustained the burden of proving racial motivation. The school board rationales thought sufficient by the court included proximity of the black school to a scrap metal yard and a major thoroughfare, lack of fireproofing of six of twenty-six rooms, and need for a new school to serve an expanding suburban population. In his dissent, Judge Sobeloff, referring to a school board member's testimony that the schools were closed because they were located in the black community, concluded that the closing was racially motivated. Id. at 619. See also Feldler v. Harnett County Bd. of Educ., 409 F.2d 1070 (4th Cir. 1969).

26 The court noted that "The motivation of individual members of a governing entity is not the same as administrative intent. Members may vote a good measure for bad reasons and vice versa. ... Regardless of motivation, the ... overriding intent was to achieve a unitary school system." 434 F.2d at 906.

27 Chambers v. Iredell County Bd. of Educ., 423 F.2d 613, 616 (4th Cir. 1970).

28 Id.

$20 \mathrm{Id}$.

30 Allen v. Asheville County Bd. of Educ., 434 F.2d 902, 906 (4th Gir. 1970).

31 Id.

$32 I d$.

33 Green v. School Bd., 330 F. Supp. 674, 677 (W.D. Va. 1971).

34 Mims v. Duval County School Bd., 447 F.2d 1330, 1332 (5th Cir. 1971).

$35 \mathrm{Id}$.

36 Id.

37 Id. 
ing teaching staff, ${ }^{38}$ vandalism, ${ }^{39}$ declining school population, ${ }^{40}$ need for "an atmosphere in which children could be successfully taught," 41 and structural building defects. ${ }^{42}$

Allowing the existence of these factors alone to justify black school closings is obviously problematic since the conditions described are closely associated with poverty and reflect the unequal treatment to which the black community has already been subjected. Nevertheless, it must be recognized that although these conditions can serve to disguise actual discriminatory intent, ${ }^{43}$ some of them could provide a rational basis for closing schools in a situation devoid of racial implications. This does not mean that all educational defenses must be accepted as justifying the closing of black schools. Rather, it is important to distinguish between two categories of considerations according to the degree of their relevance to the educational process.

The first category relates to considerations based on "educational atmosphere," "educational environment," "surrounding acreage," and the like. While conditions meeting such ambiguous criteria can be associated with schools built in white suburban communities, the relationship of the criteria to educational achievement is unclear. The concept of educational environment, moreover, is applied to schools that all meet the uniform educational standards established by the state, in order to distinguish a separate category-the optimal environment or "better" school. Vague notions of optimal educational criteria thus should not be sufficient to support decisions that will generate discriminatory burdens, continued racial stigma, and destruction of community facilities.

The second and more compelling category includes structural deficiencies that foreclose safe use of the school building and crime and violence on the school grounds; no rationale except vengeance would support the continued subjection of school children to such dangers. (In-school crime should be distinguished from neighborhood crime, which can be avoided at the minimal cost of requiring bused students to remain on school grounds throughout the school day.)

Even such structural deficiencies and in-school crime, however, should

$38 I d$

39 Id.

$40 I d$

41 Bell v. West Point Municipal Separate School Dist., 446 F.2d 1362, 1364 (5th Cir. 1971 ).

42 Gordon v. Jefferson Davis Separate School Dist., 330 F. Supp. 1119, 1122 (W.D. La.), aff'd, 446 F.2d 266 (5th Cir. 1971).

43 See Mims v. Duval County School Bd., 447 F.2d 1330, 1333 (5th Cir., 1971), where the court upheld the closing of black schools although some of the formerly white schools in the system were located on small sites or were older than some of the black schools closed. 
not automatically justify black school closings. If structural deficiencies in black schools are remediable without expenditures disproportionate to those made on white schools over time, black schools should not be closed. To some extent, the issue of in-school crime generates the same kind of conceptual difficulty. There are two alternative explanations for crime on school grounds. First, a high degree of lawlessness may exist among black students. Even if this theory were accepted, however, it would fail to justify closing black schools since black students must still be integrated with white students in some school and the choice is therefore simply the place of integration. Second, crime in school areas may be caused by the illegal entry of outsiders onto school property. But this theory also fails to justify black school closings since the problem can be remedied by providing sufficient police protection to prevent hoodlums from entering school grounds. The manageable dimensions of the problem belie the determinative weight given it by courts. Instead, a balancing test should be applied, similar to that used in the school busing context, ${ }^{44}$ in which the reduction in dollars available for education is weighed against the stigma and damage generated by unequal treatment of black students. Otherwise, governments providing the least services to black communities would be rewarded by exemption of their white citizens from their proper share of the busing burden. This result appears even less supportable in light of the recent case of Hawkins $v$. Town of Shaw, ${ }^{45}$ which indicated that unequal provision of services on racial grounds may violate equal protection. ${ }^{46}$

\section{The White Flight Problem}

By refusing to deal with the complex issues underlying the educational rationale espoused by school boards, courts have failed to provide even minimal protection against discriminatory closings of black schools. The opinions suggest that this limited standard of review is attributable to the problem posed by the flight of white students from integrated school systems. The assumption is that white students will flee the public school system if forced to attend schools in black areas. All cases have, of course, precluded formal consideration by school boards of the white flight problem; such consideration would be evidence of racial motive

44 See Brewer v. School Bd., Nos. 71-1900, 71-1901 (4th Cir., Mar. 7, 1972) (en banc); Eaton v. New Hanover County Bd. of Educ., 330 F. Supp. 78, 79 (E.D.N.C. 1971). But cf. Shapiro v. Thompson, 394 U.S. 618, 633 (1969), in which the Supreme Court held that a state may limit expenditures on public programs, but "may not accomplish such a purpose by invidious distinctions between classes of its citizens."

46437 F.2d 1286 (5th Cir. 1971), aff'd en banc, No. 29013 (5th Cir., Mar. 27, 1972).

$46 \mathrm{Id}$. at 1288. 
invalidating the school closing decision. ${ }^{47}$ Nevertheless, the Supreme Court in Swann v. Charlotte-Mecklenburg Board of Education ${ }^{48}$ emphasized workability as an important factor in school desegregation decisions. ${ }^{49} \mathrm{Also}$, in determining minimal integration ratios within schools, many courts have regarded the racial "tipping point" as a relevant consideration..$^{50}$ Moreover, courts in school closing cases, although citing educational reasons as the basis for decision, have placed major emphasis on the success of the integration effort and the necessity for a realistic plan. ${ }^{51}$ Thus, there is some evidence that courts perceive the problem as a choice between a school system integrated on terms acceptable to whites (including black school closings) or one abandoned by whites.

Although conclusive evidence is difficult to obtain, an examination of the white flight that has occurred as a result of desegregation plans suggests that the fear of white flight may be greatly exaggerated. First, the white flight phenomenon may be more significant in the short than in the long run. National Educational Association studies in Louisiana and Mississippi indicate that some whites have begun to return to the integrated public school system after fleeing previously to private white schools; ${ }^{52}$ initial fears are being replaced by optimism about the long-run viability of the public schools. ${ }^{53}$

Second, since white flight accompanies any desegregation plan, its relevance in black school closings is confined to the difference between

47 See cases cited note 17 supra.

48402 U.S. 1 (1971).

49 Swann characterized equity as "the instrument for nice adjustment . . . between public interest and private needs." Id. at I5. Courts deciding school closing cases have not been unaware of Swann's emphasis on workability. See, e.g., Gordon v. Jefferson Davis Parish School Bd., 330 F. Supp. 1119, 1120 (W.D. La. 1971).

50 See United States v. Scotland Neck City Bd. of Educ., 442 F.2d 575, 581 (4th Cir. 1971) (en banc), cert. granted, 404 U.S. 821 (1971); Calhoun v. Cook, 332 F. Supp. 804, 805-06 (N.D. Ga. 1971); Yarbrough v. Hulbert-West Memphis School Dist. No. 4, 329 F. Supp. 1059, 1064-67 (E.D. Ark. 1971); Davis v. Board of Educ., 328 F. Supp. 1197, 1201 (E.D. Ark. 1971). But cf. Watson v. Memphis, 373 U.S. 526, 536-37 (1963); Brewer v. School Bd., No. 71-1900, at 2-3 (4th Cir., Mar. 7, 1972) (en banc).

51 See Bell v. West Point Municipal Separate School Dist., 446 F.2d 1362, 1363 (5th Cir. 1971). See also Carr v. Montgomery County Bd. of Educ., 429 F.2d 382 (5th Cir. 1970). Concerns about white intransigence can be euphemistically translated into concern for " $a$ disciplined atmosphere in which a meaningful education for pupils of both races has been afforded." Bell v. West Point Municipal Separate School Dist., 446 F.2d 1362, 1363 (5th Cir. 1971).

52 "In several districts now entering their second year of desegregation, school officials reported a return of white students who had originally fled to the private academies to avoid desegregation." National Educational Ass"n, Task Force III: School Desegregation: Louisiana \& Mississippi, Nov., 1970, at 35.

53 Egerton, Report Card on Southern School Desegregation, SATURDAY REviEw, Apr. 1, 1972 , at 41,47 . 
expected flight from integration in general and that marginal increment attributable to continued maintenance of formerly black schools.

Third, white flight is often avoidable by means other than black school closings. Since the delimitation of integration plans along municipal lines provides an incentive for white flight, ${ }^{54}$ the extension of busing beyond municipal boundaries, as in the recent Richmond decision, ${ }^{55}$ could act to control future abandonment by white students. Increasing the geographic reach of the school district causes major inconveniences in fleeing the district and commuting to places of employment; the costs may eventually outweigh the fears of white parents. The only alternative to moving far from the work center is enrollment in the private school system, but private education can be extremely costly, ${ }^{56}$ especially for large families. There are indications that in some Southern districts, maintenance of a large private school system is possible only with substantial support from the public system..$^{57}$ State or federal grants to ameliorate the financial burden of private education may, however, constitute state action and bring the private schools within the requirements of the fourteenth amendment. ${ }^{.8}$ In addition, although tax exemp-

54 "The phenomenon of white flight from schools over $40 \%$ black always occurs, when it does, in cases where there are other nearly white or all white schools in a community which provide a form of refuge." Bradley v. School Bd., 338 F. Supp. 67, 197 (E.D. Va.), rev'd, No. 72-1058 (4th Cir., June 5, 1972).

55 The Richmond decision mandated the creation of a single district out of the formerly separate districts of Chesterfield County, Henrico County, and the City of Richmond. Bradley v. School Bd., 338 F. Supp. 67 (E.D. Va.), rev'd, No. 72-1058 (4th Cir., June 5, 1972). See also Bradley v. Milliken, 338 F. Supp. 582 (E.D. Mich. 1971).

56 See U.S. Comm'n on Civil Rights, Third Annual Conference on Probleais of Schools in Transition from the Educator's Viewpoint 74-79 (1961) (statement of Dr. Donald Ross Green). "[P]rivate schools currently operating generally cost substantially more than public schools." Id. at 75. "A set of private schools in lieu of public education would be expensive financially and almost disasterous educationally." Id. at 79. See also T. Pierce \& P. OrR, Our School DILemama 18-19 (1970): "The requirements for establishing a successful private school appear to be generally misunderstood and grossly underestimated. ... The outlook for adequate financial support for private schools for the long pull is dismal."

57 The NEA study reported that "[i]n many of the districts visited, there was evidence that private school students are being transported in public school buses, are using instructional materials and facilities loaned or donated from the public schools, and are being housed in buildings that were formerly public schools, leased or sold to private individuals and ultimately conveyed to private school groups. . . . The siphoning off of public moneys to segregated private school education is not only a local matter; the states of Mississippi and Louisiana are in the private school business too." National Educational Ass'n, supra note 52, at 34-35.

58 See King, Rebuilding the "Fallen House": State Tuition Grants for Elementary and Secondary Education, 84 HARv. L. REv. 1057 (1971); Comment, Public Control of Private Sectarian Institutions Receiving Public Funds, 63 Mrch. L. REv. 142 (1964). Moreover, recent Supreme Court decisions indicate the severe constitutional limitations on aid to 
tion has previously supported the growth of segregated private school systems, ${ }^{59}$ this support has been severely eroded by the recent decision in Green v. Connally, ${ }^{60}$ which denied exemptions to racially discriminatory private schools and deductions to those who contribute to them. ${ }^{61}$

Fourth, it may be assumed that the whites who flee will be significantly influenced by events within the public school system following integration. If the formerly black schools, once integrated, are provided with the necessary repairs, proper teaching staffs, and educational materials, as well as adequate police services, the experiences of white students should belie the fears of those who abandoned the public school system and encourage their return. ${ }^{62}$

It is thus arguable whether white flight should be a factor in adjudicating constitutional rights. Certainly, it should not automatically sustain the closing of black schools. Courts should at least be especially cautious of sacrificing constitutional protections for black students on the basis of so uncertain and avoidable an effect.

\section{Implementing a More Effective Standard}

The present standard of review functions analogously to the traditional equal protection test with its characteristic deference to the judgment of the administrative body ${ }^{63}$ School board classifications are sustained if any "rational basis" can be shown that would support the decision. The previous analysis has suggested, in contrast, that the appropriate standard for reviewing the closings of black schools should place a heavier burden on school boards to justify closings; moreover, it should focus on discriminatory effect rather than intent. Two legal rationales may be adopted to achieve this objective: the good faith implementation doctrine of Green v. County School Board ${ }^{64}$ and the equal protection compelling state interest test. ${ }^{65}$

parochial schools at the grade school level. See Giannella, Lemon and Tilton: The Bitter and the Sweet of Church-State Entanglement, 1971 Sur. Cr. REv. 147.

59 School Desegregation, 4 CrviL Righrs Digest 5, 10 (1971).

60330 F. Supp. 1150 (D.D.C. 1971).

61 Id. at 1164 .

62 As one observer of the Mississippi desegregation experience recently noted: "If Jackson's experience is any example, white fears will gradually diminish in the face of cumulative evidence that black and white boys and girls attend school together every day safely." Derian, White Parents' Fears, InEQuality in Education, Mar., 1972, at 23. The same author observes that some white flight may be desirable as a safety valve removing from the system the "rabidly anti-black children of rabidly anti-black parents." Id.

63 See generally Developments in the Law-Equal Protection, 82 HARv. L. REv. 1065, 1077-87 (1969) [hereinafter cited as Developments].

64391 U.S. 430 (1968).

65 See generally Developments, stpra note 63, at 1087-104. 
Green overturned a freedom-of-choice plan that in three years had produced no white student transfers to formerly black schools. The Supreme Court held that the school board plan was not a good faith effort to comply with the mandate of Brown v. Board of Education ${ }^{68}$ since it had not worked to create a unitary school system. ${ }^{67}$ Moreover, the Court stated that Brown required not merely the disestablishment of the formerely dual school system, but also the elimination of all discrimination in the system; the school board was "clearly charged with the affirmative duty to take whatever steps may be necessary to convert to a unitary system in which racial discrimination would be eliminated root and branch."68

The Court's holding in Green has direct significance for black school closings since the educational inequality in Brown sprang not from physical separation alone, but also from its symbolic impact on the students. A separate school system constitutes a denial of equal protection because it "generates a feeling of inferiority as to [the blacks'] status in the community that may affect their hearts and minds in a way unlikely ever to be undone." 69 To the extent that Brown was concerned with stigma in addition to separation, there will be a heavy presumption against the constitutionality of black school closings.

Two subsequent cases have followed the reasoning of Brown and Green to void decisions to close black schools. In Brice v. Landis, ${ }^{70}$ the district court found that a desegregation plan that included black school closings violated the good faith implementation standard of Green since the plan placed the burden of busing entirely on black students. ${ }^{71}$ The court held that the closings had a racially discriminatory effect and that other alternatives were available to distribute the busing burden more equitably. The court reasoned that to permit the school closings would make black children "second class pupils" as a result of a desegregation plan that was "substantially discriminating in itself."

The Eighth Circuit followed this rationale in Haney v. County Board of Education, ${ }^{73}$ which involved a challenge to a desegregation plan re-

66347 U.S. 483 (1954).

67391 U.S. at 441 .

68 Id. at $437-38$.

69347 U.S. at 494 . A dual school system generates "'a sense of inferiority [that] affects the motivation of a child to learn." "Id.

70314 F. Supp. 974 (N.D. Cal. 1969).

71 "Certainly, if the means selected by the District to accomplish its purported purpose, themselves involve substantial elements of racial discrimination, its entire plan becomes suspect concerning whether it is really a good faith, reasonably adequate implementation of these principles." Id. at 977.

72 Id. at 978.

73429 F.2d 364 (8th Cir. 1970). 
quiring the closing of a formerly black school. Unlike Brice, inconvenience was not a major factor since both whites and blacks were to be bused and the closed school was very close to a white school that remained open. ${ }^{74}$ The court nonetheless ignored these distinctions and focused on the stigma ${ }^{75}$ resulting from the closing and the attendant implication of inferiority of black students. Where there were allegations that children might thereby become "second class pupils," court stated that deference to administrative discretion must yield to a more critical standard of review: "[T] here is a heavy burden on the school board ... to explain the closing of facilities formerly used for the instruction of black students." 77

Despite the broad reasoning of these cases, the utility of the good faith rationale is limited to cases in which the challenged black school closings are part of a desegregation plan created in response to a court order. Where integration is undertaken solely on a voluntary basis, plaintiffs must rely on the equal protection doctrine to insure effective review. ${ }^{78}$ Measured against the compelling state interest standard, vague concepts of educational environment cannot automatically justify school closings if the attendant burden falls unequally on the black community. Where the schools closed failed to meet uniform state requirements (e.g., for building safety), the state may be able show an adequate reason for its decision. Where the closings rest on vague notions of optimal educational criteria, however, meeting the compelling state interest test will be difficult.

The state could, of course, increase its educational requirements in order to force the closing of more black schools. The applicability of the regulations to white as well as black schools, however, provides substantial protection against discriminatory treatment. Even if many black schools were closed because of the higher state standards, the closings of white schools of comparable quality would remove the stigma of blatantly unequal treatment. And if the new regulations were obviously contrived to bring about a discriminatory result, they might be subject to constitutional challenge.

Since decisions to close black schools are based on "educational factors" rather than explicit racial criteria, some courts may hesitate to

74 Id. at 372.

75 Of course, the presence of racial stigma in these cases suggests a possible violation of the thirteenth amendment, although it has never been invoked in a school closing case. For a discussion of the applicability of the thirteenth amendment to school integration, see Larson, The New Law of Race Relations, 1969 Wis. L. REv. 470, 506-10.

76429 F.2d at 371.

77 Id. at 372 .

78 See generally Developments, supra note 63, at 1087-133. 
apply the compelling state interest standard on the theory that no suspect racial classification has been demonstrated. It has long been clear, however, that neutral categories may be subject to challenges based on their functional equivalency to explicit racial classifications. ${ }^{79}$ Thus, the compelling state interest test would apply if, for whatever reason, only black schools were closed. ${ }^{80}$ A more difficult evidentiary problem arises, however, where one or more previously white schools have also been closed. Although perfect correlation between the racial group and the inequality is not required, ${ }^{81}$ as the school closing burden is distributed more evenly by closing white schools, discrimination becomes less apparent. It is unclear what specific factual showing is necessary to create the presumption that discrimination lies behind he school board decision. Where the majority of schools closed are black, the court must determine what inferences may be drawn from other elements of the factual context. The fact that the school integration resulted from a court order rather than voluntary action, for example, might complement such a statistical showing pointing in the direction of discriminatory administrative action. Department of Health, Education and Welfare guidelines on school closings adopt a similar approach by placing the burden "on the district to overcome an inference of racial motivation if the school is closed the year it would otherwise have been desegregated." 82

Thus, a combination of statistical data and reasonable factual inferences may require more careful scrutiny of black school closing deci-

79 See Smith v. Texas, 311 U.S. 128 (1940); Norris v. Alabama, 294 U.S. 587 (1935); Yick Wo v. Hopkins, 118 U.S. 356 (1886); Hawkins v. North Carolina Dental Society, 355 F.2d 718 (4th Cir. 1966). "[A]dministrative rules which function effectively as racial classifications should also be unconstitutional without a showing of an actual intent to discriminate." Developments, supra note 63, at 1099. Compare English v. Town of Huntington, 448 F.2d 319 (2d Cir. 1971), with Garret v. City of Hamtrack, 335 F. Supp. 16 (E.D. Mich. 1971).

80 The constitutional objection can focus on either the loss of the school or the inequality of the busing burden. In Spangler v. Pasadena City Bd. of Educ., 311 F. Supp. 501 (C.D. Cal. 1970), the court focused on the busing issue, concluding: "By requiring that students from two majority black residential areas . . . be transported to achieve integration, while not transporting children from majority white residential areas to achieve integration, defendants have placed an undue share of the burdens of desegregation on black children and, thus, have violated the Fourteenth Amendment." Id. at 524.

81 See Chance v. Board of Examiners, No. 71-2021 (2d Cir., Apr. 5, 1972); Hawkins v. Town of Shaw, 437 F.2d 1286, 1288 (5th Cir. 1971), aff'd en banc, No. 29013 (5th Gir., Mar. 27, 1972); Selma Improvement Ass'n v. Dallas County Comm'rs, 40 U.S.L.W. 2616 (N.D. Ala., Feb. 18, 1972); Baker v. Columbus Municipal Separate School Dist., 329 F. Supp. 706 (N.D. Miss. 1971); Armstead v. Starkville Municipal Separate School Dist., 325 F. Supp. 560 (N.D. Miss. 1971).

82 Smith Letter, supra note 1 . "OCR also requires a complete documentation of the reasons for the closing." Id. 
sions. The equal protection doctrine demands a compelling justification if the burden of such closings falls unequally on the black community. Along with the good faith implementation standard of Green, it guarantees that the stigma of separate education will not be replaced by the stigma of unequal busing and the destruction of black neighborhood schools.

Thomas S. Martin 